\title{
Kecerdasan Emosional dan Kemampuan Berpikir Kritis pada Materi Bangun Datar di Kelas Tinggi Sekolah Dasar
}

\section{Lala Nurhayati ${ }^{*}$, Luthfi Hamdani Maula ${ }^{2}$, Iis Nurasiah ${ }^{3}$ \\ 1,2,3 Pendidikan Guru Sekolah Dasar, Universitas Muhammadiyah Sukabumi, Sukabumi, Indonesia}

\section{ART ICLE INFO}

Article history:

Received March 19, 2021

Revised March 20, 2021

Accepted April 30, 2021

Available online Augsut 25, 2021

Kata Kunci:

Kecerdasan Emosional, Berpikir Kritis

\section{Keywords:}

Emotional Intelligence, Critical Thinking

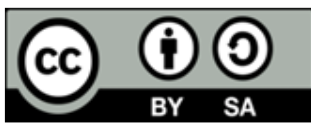

This is an open access article under the CC BY-SA license.

Copyright $@ 2021$ by Author. Published by Universitas Pendidikan Ganesha.

\begin{abstract}
A B S T R A K
Peserta didik memiliki rasa ketakutan dan kesulitan dalam pembelajaran matematika. Hal ini terjadi karena abstraksi pembelajaran matematika sulit dipecahkan dan metode mengajar yang tidak tepat. Pembelajaran matematika yang membutuhkan pikiran dan analisis yang tinggi seharusnya dimulai dari pemberian motivasi agar peserta didik menjadi rileks. Penelitian ini bertujuan untuk menganalisis hubungan kecerdasan emosional dan kemampuan berpikir kritis pada materi bangun datar di kelas tinggi sekolah dasar. Jenis penelitian yang digunakan yaitu penelitian asosiatif dengan desain korelasional dan teknik survei untuk mengetahui hubungan sebab-akibat antarvariable tanpa adanya tindakan dari peneliti. Penelitian dilaksanakan di kelas IV dengan jumlah 171 populasi. Dengan teknik pemilihan sampel purposive sampling maka sampel yang diperoleh berjumlah 64 sampel. Berdasarkan analisis data kuantitatif deskrptif, maka diperoleh hasil nilai Sig F Change $<0,001<$ 0,05 maka $\mathrm{H}_{0}$ ditolak dan $\mathrm{H}_{1}$ diterima. Hal ini menunjukkan bahwa terdapat hubungan yang positif dengan hasil 0,411 > daripada 0,246, sehingga koefisien korelasi sebesar 0,411 yang berkategori derajat hubungan sedang. Hal tersebut dapat dibuktikan dengan perolehan nilai rata-rata skor yang menunjukkan kategori baik yaitu kecerdasan emosional 73,1 dengan persentase $86,00 \%$, sedangkan kemampuan berpikir kritis 73,0 dengan persentase $91,00 \%$. Dapat disimpulkan bahwa kecerdasan emosional berhubungan dengan kemampuan berpikir kritis. Untuk meningkatakan kemampuan berpikir kritis, siswa harus mampu mengontrol emosi dalam mengikuti kegiatan pembelajaran.
\end{abstract}

A B S T R A C T

Students who have a sense of fear and difficulty in learning mathematics because the abstraction of mathematics learning is difficult to solve, inappropriate teaching methods, learning mathematics that requires high thinking and analysis should start from providing motivation so that students become relaxed. This study aims to analyze the relationship between emotional intelligence and critical thinking skills on flat-shaped material in high school grades. The type of research used is associative research with correlational design and survey techniques to determine cause-and-effect relationships between variables without any action from the researcher. The study was carried out in class IV with a population of 171, with a purposive sampling technique, the samples obtained were 64 samples. Based on descriptive quantitative data analysis, the results obtained are Sig F Change values $<0.001$ $<0.05, \mathrm{HO}$ is rejected and $\mathrm{H} 1$ is accepted. This shows a positive relationship where $0.411>$ than 0.246 , so the correlation coefficient is 0.411 which is categorized as moderate degree of relationship. This can be proven by the acquisition of an average score that shows a good category, namely emotional intelligence 73.1 with a percentage of $86.00 \%$ while critical thinking ability is 73.0 with a percentage of $91.00 \%$, it can be concluded that emotional intelligence is related to thinking ability. critical. To improve critical thinking skills, students must be able to control emotions in participating in learning activities.

\section{PENDAHULUAN}

Matematika merupakan ilmu universal yang mempunyai peranan penting dalam berbagai disiplin ilmu serta dalam mengembangkan daya pikir manusia, yang dapat mendasari perkembangan teknologi modern (Ammy \& Wahyuni, 2020; Siagian, 2016). Mata pelajaran Matematika perlu diberikan 
kepada semua peserta didik dari jenjang sekolah dasar hingga sekolah lanjutan untuk membekali peserta didik dengan kemampuan berpikir logis, analitis, sistematis, kritis, dan kreatif serta dapat menyelesaikan masalah yang dihadapinya dalam kehidupan sehari-hari (Dara Asshofi \& Damayani, 2019; Effendi et al., 2021; Handayani \& Septhiani, 2021). Ilmu matematika yang secara teori sangat memiliki keterkaitan dengan keterampilan berpikir kritis. Kemampuan berpikir kritis ini sangat penting untuk dimiliki oleh peserta didik karena di dalamnya terdapat proses aktivitas mental dalam menerima, mengolah, menganalisis, menyintesis, dan mengevaluasi informasi yang didapatkan untuk membuat suatu keputusan atau tindakan dalam memecahkan masalah (Ariani, 2020; Irawan, 2016; Suci et al., 2019).

Setiap individu mempunyai cara yang berbeda untuk mengambil keputusan dalam menyelesaikan suatu masalah atau persoalan (Mei Alfian Nita, 2017). Peserta didik yang memiliki rasa ketakutan dan kesulitan dalam pembelajaran matematika karena abstraksi pembelajaran matematika sulit dipecahkan, metode mengajar yang tidak tepat, pembelajaran matematika yang membutuhkan pikiran dan analisis yang tinggi seharusnya dimulai dari pemberian motivasi agar peserta didik menjadi rileks. Jika hal seperti ini tidak diatasi, maka sikap positif peserta didik dalam pembelajaran sulit untuk dimunculkan dan dikembangkan (Putri, 2019). Kemampuan berpikir kritis siswa masih terbilang rendah (Anggraeny et al., 2019). Hal ini dapat diketahui berdasarkan hasil penelitian TIMSS (Trends in International Mathematics and Science Study) pada tahun 2015. Indonesia berada pada peringkat ke-45 dari 50 negara peserta dengan skor 397 jauh di bawah standar skor rata-rata 600. Hal ini menunjukkan bahwa kemampuan berpikir kritis peserta didik di Indonesia masih terbilang rendah dan perlu untuk ditingkatkan. Berdasarkan wawancara dengan wali kelas di SDN Dayeuhluhur CBM Kota Sukabumi, SDN Baroskencana CBM Kota Sukabumi, SDN Cipanengah CBM Kota Sukabumi diperoleh informasi bahwa mata pelajaran Matematika sulit dipahami oleh peserta didik karena saat belajar tidak bisa mengatasi emosinya, sehingga merasakan takut tidak bisa untuk menyelesaikan permasalahan.

Motivasi peserta didik dipandang sebagai prasyarat yang diperlukan untuk kemampuan berpikir kritis. Selain itu, kondisi emosional juga turut memengaruhi kemampuan berpikir kritisnya. Peserta didik dengan suasana hati (mood) positif akan lebih konsentrasi dalam pembelajaran dan hal ini dapat mendukung kemampuan berpikir kritisnya. Kemampuan peserta didik dalam memotivasi diri dan mengelola emosi merupakan komponen dalam kecerdasan emosional (Fikri et al., 2019). Peserta didik diharapkan mampu untuk mengelola emosi dalam dirinya dengan pengelolaan emosi yang baik serta positif. Banyak penelitian yang sudah dilakukan berkaitan dengan kecerdasan emosional. Kecerdasan emosional aspek kesadaran diri berpengaruh terhadap prestasi belajar matematika (Afshara \& Masoud Rahimi, 2014; Handayani \& Septhiani, 2021; Sk \& Halder, 2020). Dengan meningkatkan kecerdasan emosional siswa dapat meningkatkan dan mengoptimalkan penguasaan konsep matematika siswa (Gusniwati, 2015; Kaya et al., 2018; Zhao et al., 2021). Kecerdasan emosional dan motivasi belajar secara bersama-sama memberikan pengaruh terhadap kemampuan berpikir kritis matematika (Sulistianingsih, 2017). Semakin baik kecerdasan emosional yang dimiliki oleh peserta didik besar kemungkinan akan semakin baik pula kemampuan seseorang dalam berpikir kritis (Harahap, 2017; Suwardi \& Suwardi, 2015). Jadi, kemampuan berpikir kritis siswa dalam menyelesaikan tugas yang baik tidak terlepas dari kecerdasan emosionalnya.

Penelitian tentang hubungan kecerdasan emosional dan kemampuan berpikir kritis sudah banyak dilakukan. Dari hasil penelitian tersebut diperoleh bahwa kecerdasan emosional berpengaruh positif dan signifikan terhadap kemampuan berpikir kritis (Anggraeny et al., 2019; Mei Alfian Nita, 2017; Sulistianingsih, 2017), kemampuan berpikir kritis siswa juga dapat dipengaruhi oleh motivasi (Harahap, 2017; Sulistianingsih, 2017). Mengembangkan kemampuan berpikir kritis diperlukan kecerdasan emosional (Hülya Kaya $\mathrm{PhD}$ et al., 2017). Penelitian ini bertujuan untuk menganalisis hubungan kecerdasan emosional dan kemampuan berpikir kritis pada materi bangun datar di kelas tinggi sekolah dasar. Kecerdasan emosional siswa akan memberikan gambaran tentang kemampuan berpikir kritis siswa dalam memecahkan permasalahan dan meningkatkan kemampuan berpikir kritisnya dalam mengelola emosinya saat mengikuti proses pembelajaran. Jadi, sangat penting dilakukan penelitian untuk menganalisis hubungan kecerdasan emosional dan kemampuan berpikir kritis.

\section{METODE}

Jenis penelitian yang digunakan yaitu penelitian asosiatif. Penelitian ini digunakan untuk melihat hubungan antara dua variabel, variabel bebas dan variabel terikat dengan maksud untuk melihat adanya keeratan hubungan antarvariable yang terdapat pada penelitian. Penelitian ini bertujuan untuk mencari hubungan yang positif atau signifikan antara kecerdasan emosional dan kemampuan berpikir kritis Matematika pada materi bangun datar di kelas IV SDN Dayeuhluhur CBM Kota Sukabumi, SDN Baroskencana CBM Kota Sukabumi, SDN Cipanengah CBM Kota Sukabumi. Data siswa yang akan dijadikan 
sampel menggunakan rumus solvin diperoleh jumlah sampel adalah 64 siswa. Metode pengumpulan data menggunakan tes uraian kemampuan berpikir kritis dan angket kecerdasan emosional. Instrumen yang digunakan berupa angket. Penelitian ini dilakukan dengan menyebarkan angket kecerdasan emosional dan tes kemampuan berpikir kritis dalam proses pembelajaran Matematika. Dengan demikian, penelitian ini menggunakan pendekatan kuantitatif deskriptif sebagaimana jenis dan teknik yang digunakan cenderung mengandalkan data kuantitatif. Data yang dikumpulkan berupa angka-angka dengan menggunakan analisis statistika yang berbantu aplikasi Microsoft excel 2016 dan SPSS 22. Prosedur penilaian angket menggunakan pengukuran skala likert untuk mengukur sikap, pendapat, dan persepsi seseorang atau sekelompok orang yang disajikan dalam bentuk checklist.

Uji validasi logis instrumen dilaksanakan dengan mempertimbangkaan orang yang berkompeten dan berpengalaman di bidangnya yang disebut dengan expert judgement. Expert Judgment yang dilakukan dalam penelitian ini yaitu peneliti langsung mengusulkan instrumen yang telah dibuat kepada 2 dosen ahli di bidangnya yaitu validator kecerdasan emosional dan validator kemampuan berpikir kritis. Upaya expert judgment agar instrumen yang akan diujicobakan kepada siswa benar-benar telah valid menurut dosen ahli. Selanjutnya, setelah melakukan expert judgment instrument diperbaiki sesuai dengan saran dosen ahli, sehingga bisa diujicobakan kembali kepada siswa. Teknik analisis data menggunakan teknik uji kolerasi dengan melakukan pengujian korelasi untuk melihat hubungan antara dua buah variable atau lebih (Lukman, 2018: 70). Analisis korelasi juga memiliki berbagai cara untuk menangani permasalahanpermasalahan yang diajukan peneliti seperti untuk mengetahui arah hubungan antarvariable, besarkecilnya keeratan pada suatu variable, dan juga untuk menguji seberapa berartinya sebuah variable (Wahyudin,2015). Untuk menjawab permasalahan tersebut digunakan analisis data menggunakan SPSS 22 dengan menentukan taraf signifikansi $\alpha=5 \%=0,05$. Untuk menentukan kriteria pengujian, antarvariable dinyatakan (jika $r>0$ ) bertanda positif, (jika $r<0$ ) bertanda negatif, sedangkan (jika $r=0$ ) bertanda tidak ada hubungan antar variable.

\section{HASIL DAN PEMBAHASAN}

Hasil

Penelitian ini dilakukan secara daring yang dilaksanakan pada tanggal 3-11 Juni 2021. Mengingat adanya wabah virus covid-19 mengakibatkan adanya peraturan pemerintah untuk tetap melakukan kegiatan di rumah (Work Form Home) termasuk peserta didik dilarang untuk mengikuti pembelajaran tatap muka di sekolah. Oleh karena itu, penelitian ini dilakukan secara daring dengan tetap mematuhi protokol kesehatan covid-19. Berikut adalah hasil analisis data desktiptif dan pengolahan data kecerdasan emosional dan kemampuan berpikir kritis. Hasil pengolahan data analisis deskriptif kecerdasan emosional diperoleh nilai minimum sebesar 60 dan nilai maksimum sebesar 86 . Nilai mean sebesar 73,1 dengan perolehan standar deviasi sebesar 13,0. Sedangkan untuk variable terikat yaitu kemampuan berpikir kritis diperoleh nilai minimum sebesar 54 dan nilai maksimum sebesar 91. Nilai mean sebesar 73,0 dengan perolehan standar deviasi sebesar 18,8. Dengan demikian, digunakan penghitungan pengategorian sebagai berikut .

Tabel 1. Kategorisasi Kecerdasan Emosional Kelas IV SDN Dayeuhluhur CBM Kota Sukabumi, SDN Baros Kencana CBM Kota Sukabumi, dan SDN Cipanengah CBM Kota Sukabumi.

\begin{tabular}{|c|c|c|c|}
\hline Kategori & Interval Skor & Frekuensi & Presentase (\%) \\
\hline Tinggi & $X \geq 86$ & 8 & $13 \%$ \\
\hline Sedang & $60 \leq X<86$ & 46 & $74 \%$ \\
\hline Rendah & $X<60$ & 8 & $13 \%$ \\
\hline \multicolumn{2}{|c|}{ Jumlah } & 62 & $100 \%$ \\
\hline
\end{tabular}

Tabel 2. Kategorisasi Kemampuan Berpikir Kritis Kelas IV SDN Dayeuhluhur CBM Kota Sukabumi, SDN Baros Kencana CBM Kota Sukabumi, dan SDN Cipanengah CBM Kota Sukabumi.

\begin{tabular}{|c|c|c|c|}
\hline Kategori & Interval Skor & Frekuensi & Presentase (\%) \\
\hline Tinggi & $X \geq 91$ & 10 & $16 \%$ \\
\hline Sedang & $54 \leq X<91$ & 41 & $66 \%$ \\
\hline Rendah & $X<54$ & 11 & $18 \%$ \\
\hline \multicolumn{2}{|c|}{ Jumlah } & 62 & $100 \%$ \\
\hline
\end{tabular}


Berdasarkan Tabel 1 dan Tabel 2 diketahui bahwa kecerdasan emosional dan kemampuan berpikir kritis memiliki tingkat kemampuan tertinggi yang sama yaitu pada ketogori sedang. Hasil perolehan tiap-tiap indikator yaitu indikator dari kecerdasan emosional dan kemampuan berpikir kritis yang akan memperlihatkan hasil perolehan persentase kemampuan peserta didik perindikator.

Tabel 3. Hasil Nilai Persentase Tiap Indikator Kecerdasan Emosional

\begin{tabular}{lllll}
\hline Indikator Kemampuan Berpikir Kritis & Tercapai & Target & Presentase & Kategori \\
\hline Memecahkan masalah & 600 & 930 & $64.52 \%$ & Cukup \\
Menganalisis & 645 & 930 & $69.35 \%$ & Cukup \\
Menyimpulkan & 605 & 930 & $65.05 \%$ & Cukup \\
Mengevaluasi & 575 & 930 & $61.83 \%$ & Cukup \\
Mensintesis & 827 & 930 & $88.92 \%$ & Baik \\
\hline
\end{tabular}

Tabel 4. Hasil Nilai Persentase Tiap Indikator Kemampuan Berpikir Kritis

\begin{tabular}{lllll}
\hline Indikator Kecerdasan Emosional & Tercapai & Target & Presentase & Kategori \\
\hline Mengenali Emosi & 204,5 & 310 & $65,97 \%$ & Cukup \\
Mengelola Emosi & 263,75 & 310 & $85,08 \%$ & Baik \\
Memotivasi Diri & 193,5 & 310 & $62,42 \%$ & Cukup \\
Membina Hubungan & 214,5 & 310 & $69,19 \%$ & Cukup \\
Mengenali Emosi Orang lain & 205,4 & 310 & $66,26 \%$ & Cukup \\
\hline
\end{tabular}

Berdasarkan Tabel 3 dan Table 4 dapat disimpulkan bahwa kecerdasan emosional memiliki 5 indikator yaitu mengenal emosi, mengelola emosi, memotivasi diri, membina hubungan, mengenali emosi orang lain. Hasil tersebut membuktikan bahwa kecerdasan emosional yang dimiliki peserta didik lebih dominan pada indikator mengelola emosi dengan persentase 85,08\% dengan pencapaian 263.73 dari target total 310. Persentase tersebut menunjukkan bahwa indikator tersebut memiliki kategori baik. Sedangkan indikator kemampuan berpikir kritis memiliki 5 indikator yaitu kemampuan memecahkan masalah, kemampuan menganalisis, kemampuan menyimpulkan, kemampuan mengevaluasi, kemampuan menyintesis. Hasil tersebut membuktikan bahwa kemampuan berpikir kritis yang dimiliki peserta didik lebih dominan pada indikator menyintesis dengan persentase 88,92\% dengan pencapaian 827 dari target total 930. Kedua indikator tersebut menunjukkan kategori baik. Uji normalitas digunakan untuk mengetahui kondisi sampel yang digunakan berdistribusi normal atau tidak (Lukman, 2018: 32). Untuk menguji hal tersebut analisis data menggunakan SPSS 22 dengan uji statistik Kolmogorov-Smirnov dan Shapiro-Wilk dengan taraf signifikansi $\alpha=5 \%=0,05$. Kriteria uji yaitu terima $\mathrm{H}_{0}$ jika nilai sig. SPSS $<\alpha=$ 0,05 atau tolak $\mathrm{H}_{1}$ jika nilai sig. SPSS $>\alpha=0,05$.

Tabel 5. Hasil Uji Normalitas Kolmogrov-Smirnov Test

\begin{tabular}{|c|c|c|c|}
\hline \multicolumn{4}{|c|}{ One-Sample Kolmogorov-Smirnov Test } \\
\hline & & & Unstandardized Residual \\
\hline $\mathrm{N}$ & & & 62 \\
\hline \multirow{2}{*}{ Normal Parameters ${ }^{\mathrm{a}, \mathrm{b}}$} & Mean & & 0,0000000 \\
\hline & Std. Deviation & & 17,21912027 \\
\hline \multirow{3}{*}{ Most Extreme Differences } & Absolute & & 0,113 \\
\hline & Positive & & 0,072 \\
\hline & Negative & & $-0,113$ \\
\hline Test Statistic & & & 0,113 \\
\hline Asymp. Sig. (2-tailed) ${ }^{c}$ & & & 0,049 \\
\hline \multirow{3}{*}{$\begin{array}{l}\text { Monte Carlo Sig. (2- } \\
\text { tailed)d }\end{array}$} & Sig. & & 0,051 \\
\hline & $95 \%$ Confidence & Lower Bound & 0,047 \\
\hline & Interval & Upper Bound & 0,056 \\
\hline a. Test distribution is Norn & & & \\
\hline
\end{tabular}

Berdasarkan hasil uji normalitas pada Tabel 5 menunjukan nilai signifikansi 0,051 > 0,05, maka dapat disimpulkan bahwa nilai residual berdistibusi normal. Dengan demikian, data penelitian tersebut layak untuk dianalisis ke uji linearlitas. Uji linearitas digunakan untuk mengetahui sampel yang digunakan memiliki spesifikasi sudah benar atau tidak, bertujuan untuk memperoleh bukti yang berbentuk linear (Jubilee, $2014: 47$ ). 
Tabel 6. Hasil Uji Linearlitas

\begin{tabular}{|c|c|c|c|c|c|c|c|}
\hline \multicolumn{8}{|c|}{ ANOVA Table } \\
\hline & & & $\begin{array}{c}\text { Sum of } \\
\text { Squares }\end{array}$ & $\mathrm{df}$ & Mean Square & $\mathrm{F}$ & Sig. \\
\hline Unstandardized & Between & (Combined) & 13114,684 & 30 & 437,156 & 2,726 & 0,003 \\
\hline Residual * & Groups & Linearity & 0,000 & 1 & 0,000 & 0,000 & 1,000 \\
\hline Unstandardized & & Deviation from & 13114,684 & 29 & 452,230 & 2,820 & 0,003 \\
\hline \multirow[t]{3}{*}{ Predicted Value } & & Linearity & & & & & \\
\hline & Within G & & 4971,700 & 31 & 160,377 & & \\
\hline & Total & & 18086,384 & 61 & & & \\
\hline
\end{tabular}

Berdasarkan Tabel 6 maka dapat disimpulkan bahwa nilai Sig. Linearity yaitu 1,000 > 0,05 maka terdapat hubungan yang linear antara variabel bebas dan terikat. Dengan demikian, kedua variable bebas dan terikat atau variable kecerdasan emosional dan kemampuan berpikir kritis memiliki hubungan yang linear. Oleh karean itu, analisis data penelitian tersebut layak untuk dilanjutkan ke tahap berikutnya yaitu pengujian analisis. Setelah dilakukan uji normalitas dan uji linearlitas, maka tahap selanjutnya pengujian korelasi pearson untuk mengetahui hubungan antara variabel kecerdasan emosional dan kemampuan berpikir kritis pada materi bangun datar di kelas tinggi sekolah dasar.

Tabel 7. Hasil Uji Korelasi

\begin{tabular}{|c|c|c|c|c|c|c|c|c|c|}
\hline \multicolumn{10}{|c|}{ Model Summary } \\
\hline \multirow[b]{2}{*}{ Model } & \multirow[b]{2}{*}{$\mathbf{R}$} & \multirow[b]{2}{*}{ R Square } & \multirow[b]{2}{*}{$\begin{array}{l}\text { Adjusted } \\
\text { R Square }\end{array}$} & \multirow[b]{2}{*}{$\begin{array}{l}\text { Std. Error of } \\
\text { the Estimate }\end{array}$} & \multicolumn{5}{|c|}{ Change Statistics } \\
\hline & & & & & $\begin{array}{c}\text { R Square } \\
\text { Change }\end{array}$ & F Change & df1 & df2 & $\begin{array}{c}\text { Sig. F } \\
\text { Change }\end{array}$ \\
\hline 1 & $0,411^{\mathrm{a}}$ & 0,169 & 0,155 & 17,36202 & 0,169 & 12,217 & 1 & 60 & $<0,001$ \\
\hline
\end{tabular}

Selanjutnya dilakukan penarikan kesimpulan, diketahui bahwa nilai signifikansi f change lebih kecil dari 0,05 maka dapat disimpulkan bahwa antara variable kecerdasan emosioal berhubungan dengan variable kemampuan berpikir kritis, yaitu nilai Sig F Change $<0,001<0,05$, maka antara variabel bebas dan variable terikat memiliki hubungan yang signifikan. ntuk melihat tingkat keeratan hubungan tersebut dapat dilihat pada nilai R. Rumus yang digunakan yaitu rumus Product Moment Coefficient, nilai R disini dimaksud dengan koefesien korelasi dengan nilai 0,411. Untuk mengetahui tingkat keeratan hubungan yaitu dengan cara membandingkan dengan taraf signifikansi $\alpha=5 \%=0,05 \mathrm{r}_{\text {tabel }}$ dari $\mathrm{N}=62$ yaitu 0,246 Setelah dilakukan penghitungan dinyatakan bahwa 0,411 > daripada 0,246. Dengan demikian, diperolehlah hasil penghitungan antara variabel bebas (x) yaitu kecerdasan emosional memiliki hubungan yang positif terhadap variabel terikat (y) yaitu kemampuan berpikir kritis, Adapun derajat hubungan yang dimiliki yaitu sebesar 0,411 dengan ketegori derajat hubungan sedang.

Berdasarkan hasil penelitian, kecerdasan emosional berpengaruh yang signifikan terhadap kemampuan berpikir kritis matematika. Kemampuan berpikir kritis merupakan kesanggupan seseorang untuk berpikir menggabungkan hal yang kualitatif dan kuantitatif (Firdaus et al., 2019; Irawan, 2016). Kemampuan berpikir kritis ini dapat membantu seseorang dalam menangkap pelajaran yang tengah berlangsung (Erdogan, 2019; Sk \& Halder, 2020). Seseorang akan sangat membutuhkan kemampuan berpikir kritis yang baik guna membantu ia dalam memahami materi pada semua pelajaran termasuk dalam pelajaran Matematika. Matematika dipelajari secara umum mulai dari tingkat TK hingga perguruan tinggi. Matematika erat kaitannya dengan kehidupan sehari-hari (Irawan, 2016; Sulistianingsih, 2017). Kenyataannya, banyak sekali orang yang kerap kali menganggap Matematika sebagai suatu hal yang sulit karena Matematika selalu berkaitan dengan angka dan rumus. Anggapan tersebut muncul karena rendahnya kemampuan berpikir kritis Matematika yang dimilikinya. Kemampuan berpikir kritis dapat dipengaruhi oleh beberapa faktor, salah satu diantaranya adalah kecakapan seseorang dalam mengelola emosi atau yang biasa disebut sebagai kecerdasan emosional. Jika kecerdasan emosional semakin baik, maka semakin tinggi kemampuan berpikir kritis yang dimiliki oleh orang tersebut.

Hal itu telah terbukti dari hasil penelitian yang telah dihitung di atas bahwa terdapat korelasi (hubungan) antara kecerdasan emosional dan kemampuan berpikir kritis Matematika. Artinya, terdapat pengaruh antara kecerdasan emosional dan kemampuan berpikir kritis Matematika. Sekolah sebagai lembaga formal dapat mencetak sumber daya manusia dengan kualitas yang baik. Di dalam sekolah, banyak sekali interaksi selama kegiatan belajar mengajar berlangsung. Interaksi tersebut akan melibatkan emosi dan juga motivasi seseorang dalam belajar, sehingga dapat memengaruhi kemampuan berpikir 
kritis seseorang. Seseorang yang memiliki kecerdasan emosional dan motivasi belajar yang baik, umumnya tingkat kemampuan berpikir kritisnya pun akan baik pula (Costa et al., 2021; Gunarsih, 2016). Kemampuan berpikir kritis ini dapat menjadi indikator keberhasilan seseorang dalam melakukan kegiatan pendidikan, sehingga kemampuan berpikir kritis harus dibangun dengan sebaik-baiknya dalam setiap pelaksanaan pembelajaran(Li et al., 2021; Polat \& Aydın, 2020). Kecerdasan Emosional (EQ) dan bentuk kecerdasan lainnya sebenarnya saling melengkapi dan saling menyempurnakan (Afshara \& Masoud Rahimi, 2014; Kaya et al., 2018). Emosi dapat membangun kreativitas, kolaborasi, inisiatif, dan transformasi, sedangkan penalaran logis berfungsi mengatasi dorongan-dorongan yang keliru serta menyelaraskan tujuan, proses, dan teknologi dengan manusiawi (Lee \& Sook-Young Kim, 2021; Nurdiansyah, 2016). Temuan ini diperkuat dengan penelitian sebelumnya yang menyatakan kecerdasan emosional berpengaruh terhadap prestasi belajar Matematika (Handayani \& Septhiani, 2021). Kecerdasan emosional siswa juga dapat meningkatkan penguasaan konsep Matematika siswa (Fikri et al., 2019; Gusniwati, 2015). Kecerdasan emosional dan motivasi belajar secara bersama-sama memberikan pengaruh terhadap kemampuan berpikir kritis Matematika (Sulistianingsih, 2017). Semakin baik kecerdasan emosional yang dimiliki oleh peserta didik besar kemungkinan akan semakin baik pula kemampuan seseorang dalam berpikir kritis (Harahap, 2017; Suwardi \& Suwardi, 2015). Jadi, kecerdasan emosional dan kemampuan berpikir kritis adalah hal yang tidak bisa dipisahkan. Kecerdasan emosional akan mengoptimalkan kemampuan berpikir kritis siswa. Dengan memiliki kemampuan berpikir kritis yang baik akan memengaruhi hasil belajar siswa menjadi lebih baik. Untuk itu, siswa harus mampu mengontrol emosi dalam mengikuti kegiatan pembelajaran.

\section{SIMPULAN}

Kecerdasan emosional yang baik akan memengaruhi kemampuan berpikir kritis siswa dalam memecahkan suatu permasalahan. Jika kecerdasan emosional baik, maka kemampuan berpikir kritis baik yang secara langsung memengaruhi hasil belajar. Untuk meningkatkan kemampuan berpikir kritis, siswa harus mampu mengontrol emosi dalam mengikuti kegiatan pembelajaran

\section{DAFTAR PUSTAKA}

Afshara, H. S., \& Masoud Rahimi. (2014). The Relationship among Critical Thinking, Emotional Intelligence, and Speaking Abilities of Iranian EFL Learners. Procedia - Social and Behavioral Sciences, 136(9), 75-79. https://doi.org/10.1016/j.sbspro.2014.05.291.

Ammy, P. M., \& Wahyuni, S. (2020). Analisis Motivasi Belajar Mahasiswa Menggunakan Video Pembelajaran sebagai Alternatif Pembelajaran Jarak Jauh (PJJ). Jurnal Matematics Pedagogic, 5(1), 27-35. http://jurnal.una.ac.id/index.php/jmp/article/view/1354.

Anggraeny, T. K., Rohana, R., \& Jayanti, J. (2019). Pengaruh Pendekatan Metaphorical Thinking terhadap Kemampuan Berpikir Kritis dan Kecerdasan Emosional Siswa SMAN 4 Kayuagung. Jurnal Pendidikan Matematika RAFA, 5(1), 57-69. https://doi.org/10.19109/jpmrafa.v5i1.3001.

Ariani, T. (2020). Analysis of Students' Critical Thinking Skills in Physics Problems. Physics Educational Journal, 3(1), 1-13. https: //doi.org/10.37891/kpej.v3i1.119.

Costa, M. G. da, Pinto, L. H., Martins, H., \& Vieira, D. A. (2021). Developing Psychological Capital and Emotional Intelligence in Higher Education: A Field Experiment with Economics and Management Students. The International Journal of Management Education, 19(3), 100516. https://doi.org/10.1016/j.ijme.2021.100516.

Dara Asshofi, M. P., \& Damayani, A. T. (2019). Peningkatan Hasil Belajar Matematika Materi Faktor Persekutuan Besar dan Kelipatan Persekutuan Kecil melalui Model NHT Berbantu Media Papan Puzzle Berbintang. Jurnal Ilmiah Sekolah Dasar, 3(4). https://doi.org/10.23887/jisd.v3i4.21881.

Effendi, R., Herpratiwi, \& Sutiarso, S. (2021). Pengembangan LKPD Matematika Berbasis Problem Based Learning di Sekolah Dasar. Jurnal Basicedu, 5(2), 920-929. https://doi.org/10.31004/basicedu.v5i2.846.

Erdogan, V. (2019). Integrating 4C Skills of 21st Century into 4 Language Skills in EFL Classes. International Journal of Education and Research, 7(11), 113-124.

Fikri, K., Yani, A., \& Ijuddin, R. (2019). Hubungan Kecerdasan Emosional dan Kemampuan Berpikir Kritis Matematis Siswa Kelas X SMA Negeri 1 Pontianak. Fkip Prodi Matematika Untan Pontianak, 2.

Firdaus, A., Nisa, L. C., \& Nadhifah, N. (2019). Kemampuan Berpikir Kritis Siswa pada Materi Barisan dan Deret Berdasarkan Gaya Berpikir. Jurnal, 10(1), 68-77. https://doi.org/10.15294/kreano.v10i1.17822.

Gunarsih, F. D. (2016). Hubungan Interaksi Sosial, Konsep Diri, dan Kecerdasan Emosional terhadap 
Prestasi Belajar Matematika Siswa Kelas VIII SMP Negeri DI Kecamatan Pituruh. EKUIVALEN, 20(2), 211-216. https://doi.org/10.37729/ekuivalen.v20i3.2901.

Gusniwati, M. (2015). Pengaruh Kecerdasan Emosional dan Minat Belajar terhadap Penguasaan Konsep Matematika Siswa SMAN di Kecamatan Kebon Jeruk. Jurnal Ilmiah Pendidikan MIPA, 5(1), 26-41. https://doi.org/10.30998/formatif.v5i1.165.

Handayani, D., \& Septhiani, S. (2021). Pengaruh Kecerdasan Emosional Aspek Kesadaran Diri terhadap Prestasi Belajar Matematika. Jurnal Cendekia: Jurnal Pendidikan Matematika, 05(02), 1352-1358. https://doi.org/10.31004/cendekia.v5i2.585.

Harahap, S. K. \& H. S. (2017). Hubungan Konsep Diri dan Kecerdasan Emosional terhadap Hasil Belajar Biologi Siswa di Kelas XI IPA SMA. Jurnal Pendidikan Biologi, 6(3), 361-366. https://doi.org/10.24114/jpb.v6i3.8041.

Hülya Kaya PhD, B., Emine Şenyuva PhD, B., \& Gönül Bodur PhD, B. (2017). Developing Critical Thinking Disposition and Emotional Intelligence of Nursing Students: A Longitudinal Research. Nurse Education Today, 48, 72-77. https://doi.org/10.1016/j.nedt.2016.09.011.

Irawan, A. (2016). Peranan Kemampuan Numerik dan Verbal dalam Berpikir Kritis Matematika pada Tingkat Sekolah Menengah Atas. Jurnal Ilmiah Pendidikan Matematika, Ilmu Matematika Dan Matematika Terapan, 6(2), 121-130. https://doi.org/10.12928/admathedu.v6i2.5443.

Kaya, H., Şenyuva, E., \& Gönül Bodur. (2018). The Relationship between Critical Thinking and Emotional Intelligence in Nursing Students: A LongitudinalSstudy. Nurse Education Today, 68, 26-32. https://doi.org/10.1016/j.nedt.2018.05.024.

Lee, J.-Y., \& Sook-Young Kim. (2021). Mediating Effects of Emotional Intelligence and Resilience on the Relationship between Type D Personality and Caring Ability in Nursing Students: A crossSectional Study. Nurse Education Today, 16, 105151. https://doi.org/10.1016/j.nedt.2021.105151.

Li, Y., Li, K., Wei, W., Dong, J., Wang, C., Jiaxin, Y. F., \& Li Xin Peng. (2021). Critical thinking, Emotional Intelligence and Conflict Management Styles of Medical Students: A Cross-Sectional Study. Thinking Skills and Creativity, 40,100799. https://doi.org/10.1016/j.tsc.2021.100799.

Mei Alfian Nita. (2017). Pengaruh Kecerdasan Emosional terhadap Kemampuan Berpikir Kritis Siswa pada Pokok Bahasan Barisan dan Deret Aritmatika Kelas XI Program Keahlian Jasa Boga di SMA Negeri 1 Ngasem. Simki-Techsin, 01(01), 1-7.

Nurdiansyah, E. (2016). Pengaruh Kecerdasan Spiritual, Kecerdasan Emosional, Dampak Negatif Jejaring Sosial dan Kemampuan Berpikir Divergen terhadap Hasil Belajar Matematika Siswa. Journal of Educational Science and Technology (EST), 2(3), 171. https://doi.org/10.26858/est.v2i3.3216.

Polat, Ö., \& Aydın, E. (2020). The Effect of Mind Mapping on Young Children's Critical Thinking Skills. Thinking Skills and Creativity, 38. https://doi.org/10.1016/j.tsc.2020.100743

Putri, D. P. (2019). Peran dan Kontribusi Ilmuwan Muslim dalam Pembelajaran Matematika. ARITHMETIC: Academic Journal of Math, 1(1), 63. https://doi.org/10.29240/ja.v1i1.822.

Siagian, M. D. (2016). Kemampuan Koneksi Matematik dalam Pembelajaran Matematika. MES: Journal of Matematics Education and Science2, 2(1), 58-67. https://doi.org/10.30743/mes.v2i1.117.

Sk, S., \& Halder, S. (2020). Critical Thinking Disposition of Undergraduate Students in Relation to Emotional Intelligence: Gender as a Moderator. Heliyon, 6(11). https: //doi.org/10.1016/j.heliyon.2020.e05477.

Suci, D. W., Firman, F., \& Neviyarni, N. (2019). Peningkatan Keterampilan Berpikir Kritis Siswa melalui Pendekatan Realistik di Sekolah Dasar. Jurnal Basicedu, 3(4), 2042-2049. https://doi.org/10.31004/basicedu.v3i4.229.

Sulistianingsih, P. (2017). Pengaruh Kecerdasan Emosional dan Motivasi Belajar terhadap Kemampuan Berpikir Kritis Matematika. JKPM (Jurnal Kajian Pendidikan Matematika), 2(1), 129-139. https://doi.org/10.30998/jkpm.v2i1.1899.

Suwardi, S. A., \& Suwardi, S. (2015). Pengaruh Pola Asuh Demokratis, Interaksi Sosial Teman Sebaya, Kecerdasan Emosional, dan Efikasi Diri terhadap Hasil Belajar Matematika Siswa Kelas VIII SMPN Se Kecamatan Manggala di Kota Makassar. Jurnal Daya Matematis, 3(1), 10. https: //doi.org/10.26858/jds.v3i1.1292.

Zhao, J., Zheng, H., Zhong, C. W., J.Vijayashree, \& J.Jayashreed. (2021). Moderating Role in the Relationship between Job Stress and Deviant Emotional Intelligence in Education. Aggression and Violent Behavior, 101626. https://doi.org/10.1016/j.avb.2021.101626. 